possible by generous financial support from Messrs. G. N. Haden and Sons and Messrs. Pilkington Bros. Ltd. Dr. Hopkinson's aim will be to educate architects, engineers and scientists in ways of designing buildings that are pleasant and stimulating to live in, and at the same time functionally efficient and economical. He will be concerned with lighting, air conditioning, heating and the problems of noise. He will promote greater co-operation between engincers and architects, and encourage scientific research into the problems of improving human environmont. Courses of study in which engineers, architects and research workers will work together will be set up at University College. Dr. Hopkinson is at present in charge of research on the lighting of buildings at the Building Research Station of the Department of Scientific and Industrial Research. His pioneer work on human adaptability and research into the noeds of the human being in his environment has brought him into contact with architocts and research workers throughout the world, and has resulted in many papers and publications, of which perhaps the most significant is his book Architectural Physics: Lighting published by H.M.S.O. in 1963. Dr. Hopkinson has lectured on environmental design in many universities in Britain and overseas and has acted as the University's 'opponent' in a 'doctorate disputation' in Stockholm, and he has directed a research programme in the Department of Electrical Engineering at Cornell University, where he spent a term as a visiting professor. He will take up his new post early in $\mathbf{1 9 6 5 .}$

\section{The British Joint Corrosion Group}

THE Councils of the Iron and Steel Institute and the Institute of Metals, together with the Council of the Society of Chemical Industry, have considered how best to meet the needs of corrosion specialists, metal producers, and metal users with regard to information concerning corrosion and its prevention. 'The excellent work of the Corrosion Group of the Society of Chemical Industry is fully acknowledged, but it has been recognized for some time that the publications of, and the discussions arranged by, the two institutes have not adequately catered for the interests of those of their members particularly concerned with the metallurgical aspects of corrosion, nor with the interests of those members who are corrosion specialists. The councils of the three societies have now agreed to form a joint group to be known as the British Joint Corrosion Group, with the view of: (a) providing a forum for discussion of papers on corrosion and protection of metals; (b) overcoming the present dispersion of papers dealing with corrosion throughout many publications, and strengthening the facilities for publishing such papers; (c) improving the arrangements for publication and discussion of the metallurgical aspects of corrosion; (d) representing United Kingdom corrosion interests internationally. The Institute of Metal Finishing was invited to join the Group and has accepted the invitation. The functions of the existing Corrosion Group of the Society of Chemical Industry will be incorporated into the new organization, and the co-operation of other bodies concerned with this field is also being sought.

Members of the four societies are entitled to register as members of the Group and, on so doing, to receive notices of Group meetings, and to attend such meetings without further payment. The Group will be administered by an organizing committee composed of representatives of the societies. A new publication to be called The British Corrosion Journal will be launched, sponsored by the Group, and controlled by a Publication Committee. The first issue of the Journal, which will be published in alternate months, will be circulated in July 1965. The Society of Chemical Industry will service the new Group, and provide editorial facilities for the Group's Journal. Manuscripts of papers submitted to the new Journal should be sent to the Editor, The British Corrosion Journal, 14 Belgrave Square, London, S.W.1. Members of the four co-operating societies are invited to register now as members of the British Joint Corrosion Group. Further information, and application forms for subscription to the Journal, can be obtained from the Secretary, the British Joint Corrosion Group, 14 Belgrave Square, London, S.W.1.

\section{Interferon Information Exchange Group}

AN information exchange group for research on interferon has been formed. The objectives and operations of an earlier established information exchange group have already been described in Science $(143,308 ; 1964)$. The new exchange will make it possible for a scientist working on interferon to communicate research findings or other scientific information quickly to all others in the same field throughout the world. Under the new scheme, the exchange member will send his communication to the exchange 'centre' where duplicate copies will be printed (by photooffset) and distributed. Communications will include manuscripts (which will also have been sent to journals), discussions, criticisms, bibliographic omissions, memoranda of unpublished research findings, technical suggestions, unofficial notes of meetings or any other original communications. No editorial prerogatives will be exercised. Active investigators of interferon who did not receive the announcement letter are invited to apply for membership. The chairman is Dr. Alick Isaacs, National Institute for Medical Research, London, N.W.7, and the co-chairman, Dr. Samuel Baron, Laboratory of Biology of Viruses, National Institute of Allergy and Infectious Diseases, Bethesda, Maryland 20014. All correspondence should be sent to the co-chairman.

\section{Advanced Educational Courses}

A Bulletin issued by the London and Home Counties Regional Advisory Council for Technological Education describes the special advanced courses held in the London and Home Counties Region, which do not regularly appear in college calendars or prospectuses as part of a grouped course or as subjects offered for endorsement on Higher National Certificates (Bulletin of Special Courses in Higher Technology, Management Studies and Commerce, 1964-65. Part 1: Autumn Term. Pp. 126. London: London and Home Counties Regional Advisory Council for Technological Education, 1964. 5s.). As a rule they are parttime courses (usually evening), but full-time courses, which are specially arranged and are not longer than three months duration, are also included. Sessional evening postgraduate courses leading to higher degrees in science (including mathematics) and engineering are not included. Among the wide variety of courses are: cost engineering in the process industries (Borough Polytechnic); varactor diodes (Brunel College); silicon gate-controlled switches (Enfield College of Technology); high fidelity sound reproduction (Hendon College of Technology); predetermined motion time standards (Kingston College of Technology); management for the clothing trade (London College of Fashion); geotechnical processes and soil stabilization (Northampton Collego of Advanced Technology); tall buildings (The Polytechnic); trading blocs (Slough College); and autocode programming (Wimbledon Technical College).

\section{Royal Society Films for Hire}

IN 1961 the Royal Society mounted an expedition to Sabah, North Borneo. The purpose of tho expedition was to study the undisturbed forest life and soil variation at different altitudes of Mount Kinabalu and the Pinosuk Plateau. A film was prepared by members of the expedition showing some aspects of their work, and has now been made available by the Royal Society for hire by schools, educational institutions, film socioties, etc. The film is of approximately $35 \mathrm{~min}$ duration and is in colour with a dialogue. The charge for hiring is $25 s$. Other films available from the Royal Society are: "The Volcanic 